\title{
Comments
}

\section{JURISDICTION OF THE CALIFORNIA CORPORATIONS COMMISSIONER OVER DELAWARE SHORT FORM MERGERS}

In the conventional statutory merger, a shareholder in a disappearing corporation has the right to receive stock in the surviving corporation or to demand a cash payment for the value of his shares. ${ }^{1}$ Under the Delaware "short form" inerger statute, ${ }^{2}$ which provides a method whereby a parent corporation may merge with its less than wholly-owned subsidiary, the choice of whether a minority shareholder will receive stock or be paid in cash rests with the parent corporation, not with the shareholder. Delaware's short form merger statute has been interpreted by that state's supreme court to permit a parent corporation owning ninety percent or more of its subsidiary's outstanding stock to eliminate the minority shareholders from continuing participation in the enterprise by paying them the value of their shares in cash. ${ }^{3}$

While a Delaware parent corporation could not effect a short form merger with a subsidiary incorporated in California, ${ }^{4}$ a California corporation may nevertheless be involved in the short form merger process as the following hypothetical demonstrates. ${ }^{5}$

Delaware Pump Corporation, interested in expanding its operations to the West Coast, attempts to gain complete control of California Pump and Supply Company by the following three-step procedure: (1) An acquisition by the Delaware corporation of a majority of the outstanding

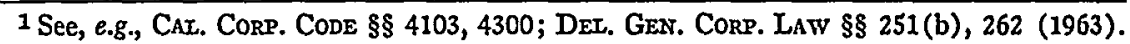

2 Det. Gen. Corp. Law $\$ 253$ (Supp. 1962).

3 Coyne v. Park \& Tilford Distillers Corp., 154 A.2d 893 (Del. 1959); Stauffer v. Standard Brands Inc., 187 A.2d 78 (Del. 1962). See notes 17-20 infra and accompanying text.

4 DeL. Gen. CoRp. LAW $\$ 253$ (a) (Supp. 1962). This section provides that a domestic corporation may merge with a foreign corporation if the laws of the foreign corporation permit "such a merger." Presumably, "such a merger" means a merger between a parent and a subsidiary where the parent owns at least $90 \%$ of the outstanding stock of the subsidiary. California, however, permits a short form merger only where the subsidiary is wholly-owned by the parent corporation. CAL. CORP. CODE $\$ 4124$.

5 The steps outlined in the hypothetical are essentially those taken by a Delaware corporation in Stauffer v. Standard Brands Inc., 187 A.2d 78 (Del. 1962). In that case, however, a California corporation was not involved.

The foreign corporation which is attempting to gain control of Califorma Pump and Supply Company need not be a Delaware corporation. Colorado, Iowa, Mississippi, New York, North Dakota, South Carolina, Tennessee, and Utal have similar short form merger statutes, and corporations organized under the laws of these states could be substituted for the Delaware corporation throughout the following discussion. See notes 14-16 infra and accompanying text. 
shares of the California corporation; (2) a merger of the California corporation into a subsidiary created by the Delaware corporation expressly for the purpose of merger, or alternatively, a sale of assets by California Pump to the Delaware subsidiary in exchange for the latter's shares $;^{6}$ and (3) a "short form" merger between the Delaware parent and the Delaware subsidiary."

This Comment exammes the jurisdictional problems the California Corporations Commissioner will encounter in protecting minority shareloolders during a "takeover" of a California corporation by a foreign corporation using this three-stage process culminating in a short form merger. Part I discusses the short form merger and the relevant state statutes. Part II sets forth the essential concepts of California blue sky regulation. Part III examines the three steps of the corporate "takeover" and the problems of jurisdiction of the California Corporations Commissioner in supervising each step.

\section{THE SHORT FORM MERGER: PRINCIPAL CHARACTERISTICS}

In the typical statutory merger, two or more corporations unite pursuant to a specified statutory procedure. Generally, the board of directors of each merging corporation must pass a resolution enconpassing the terms of the merger which must then be approved by a specified percentage of the stockholders. ${ }^{8}$ Shareholders of a disappearing corporation who desire to continue their investnient have a right to receive shares in the surviving corporation; those who dissent may force the corporation in which they held stock or the surviving corporation, depending upon the statute, to purchase their shares at fair market value. ${ }^{9}$ The statutes further provide for a right of "appraisal"-a judicial determination of

\footnotetext{
${ }^{6}$ Such an exchange of assets for shares leaves the California corporation in essence a holding company, with its only assets being stock in the Delaware subsidiary. Following a dissolution of the California corporation and a distribution of the stock to shareholders, a de facto merger has been achieved. See generally, Hills, Consolidation of Corporations by Sale of Assets and Distribution of Shares, 19 CarIF. L. Rev. 349 (1931); Comment, 35 MrCH. L. REv. 626 (1937).

7 A similar "takeover" technique was used in Braasch v. Goldschmidt, 199 A.2d 760 (Del. Ch. 1964). $X$, a Netherlands corporation, owning 50\% of the outstanding stock of $Y$, a Delaware corporation, niade an offer to the other shareholders to buy their shares. The offer was accepted by a sufficient number of $Y$ sharcholders to give $X$ ownership of over $90 \%$ of $Y$ 's stock. A year Iater, $X$ organized $Z$ as its wholly-owned subsidiary under Delaware law, and transferred to it all of the stock in $Y$ which it owned. Then $X$ engineered a short form merger between $Y$ and $Z$, the minority shareholders of $Y$ being offered cash for their securities in lieu of securities in the surviving corporation.

8 See, e.g., CAL. CoRP. CODE $\$ \S 4103,4107$.

9 Compare CAL. CORP. CodE $\S 4300$ with DEL. Gen. Corp. LAW $\S 262$ (b) (1963).
} 
the fair market value of the stock if the dissenting shareholder and the corporation cannot agree thereon. ${ }^{10}$

The short form merger is a simplified procedural device for effecting fusion between a parent corporation and one or more subsidiaries. Unlike the statutory merger, it may proceed without the approval of the stockholders of the parent corporation, at least where the parent corporation survives the merger. ${ }^{11}$ In addition, neither the directors nor the stockholders of the subsidiary have a voice in the matter..$^{12}$ Typically, the board of directors of the parent corporation passes a resolution to merge, the necessary papers are filed with the appropriate state official, and the merger is complete upon notification of the stockholders. ${ }^{13}$ Twelve states

10 See, e.g., Cat. Corp. Code $\$ \S 4300-18$; Dex. Gen. Corp. Law $\$ 262$ (1963). At common law, unamimous sbareholder approval was required before a fundamental corpornte change could take place. The need for corporate flexibility, however, led states to reduce the percentage of the shareholder vote required to effect the proposed change. The appraisal remedy developed simultaneously to compensate the shareholder for the loss of his commonlaw right to block or prevent a merger, consolidation, or other fundamental change. Lattin, Minority and Dissenting Shareholders' Rights in Fundamental Changes, 23 LAW \& ConteMr. Рвов. 307, 308-10 (1958); Wolf, Dissenting Shareholders: Is the Statutory Appraisal Remedy Exchusive?, 42 Texas L. Rev. 58, 59 (1963).

11 See Des. Gen. Corp. Law \& 253(a) (Supp. 1962). This section states that where the parent is not the surviving corporation, however, approval by a majority of the parent's stockholders may be necessary.

12 See statutes cited at notes 14-15 infro. The freedom from the necessity of shareholder approval in a short form merger is an even greater step in corporate flexibility. The rationale is that there can never be a sufficient percentage of minority sbareholders to block the merger and that appraisal rights provide an adequate remedy for any unfair treatment which the minority might receive. MOdEI Bus. CoRP. ACT ANN. § 68A If 4 (1960); Johnstone \& Galloway, Mergers, Consolidations, and Asset Sales, 15 S.C.L. Rev. 415, 419 (1963).

The adequacy of the appraisal remedy, however, is often questionable. The dissenting stockholder has only 20 days to assert his right. See, e.g., DeL. GEN. Corp. LAw \& 262(b) (1963); N.Y. STOCK CoRp. LAW § 85(7). If demand for payment of the fair market value of his slares is not made within that time, the slareliolder must usually accept the price which the parent sets forth in the certificate of merger. Stauffer v. Standard Brands Inc., 187 A.2d 78 (Del. 1962). In addition, especially in the case of closely held corporations, there is generally dificulty in establishing exactly what the fair market value is. See Manming, The Shareholder's Appraisal Remedy: An Essay for Frank Coker, 72 YaLE L.J. 223, 231-32 (1962).

Finally, an appraisal right of a California resident exercisable only in Delaware may be of dubious value. See Sobieski, State Blue Sky Jurisdiction Over Foreign Corporations, 14 Hastings L.J. 75, 79 (1962). For an account of some of the difficulties a minority slareholder may have in asserting his appraisal right, see Rank Organization Ltd. v. Pathe Lab., Inc., 30 Misc. 2d 748, 227 N.Y.S.2d 562 (1962).

13 See, e.g., Dex. Gew. CoRp. Law § 253 (Supp. 1962); S.C. Code § 12-20.5(a) (Supp. 1963). The notice provisions of the statutes vary. In Delaware, for example, notice of the fact of merger must be sent to the shareholders within ten days after the date on which the requisite papers are filed with the Secretary of State. DEL. GEN. Corp. LAw \& 253(e) (Supp. 1962). In South Carolina, the statute calls for a thirty-day waiting period between notice of the proposed merger to the shareholders and the filing of the necessary papers. S.C. CoDE \& 12-20.5(a)(3) (Supp. 1963). 
permit a short form merger only between a parent and a wholly-owned subsidiary, ${ }^{14}$ while ten states permit such a merger where the parent owns less than one-hundred percent of the subsidiary's outstanding stock. ${ }^{15}$ In several states, the procedure is available only when the business of the subsidiary is incidental or similar to that of the parent corporation. ${ }^{16}$

Of the ten states that permit a short form merger, even though the parent corporation does not own all of the outstanding stock of its subsidiary, nine have a provision which permits the parent corporation to pay cash upon the surrender of the minority shares. ${ }^{17}$ Two of these cash-forshares provisions ${ }^{18}$ have received judicial construction, the courts holding that while the minority shareholder has a right of appraisal, he has no right to receive shares in the surviving corporation. ${ }^{19}$ Ceasing to be merely a procedural device to facilitate a merger, the short form merger thus gives the parent corporation the substantive power to force a sale by the minority shareholders and to summarily eliminate them from continuing participation in the enterprise. ${ }^{20}$ Despite its apparent unfairness, ${ }^{21}$ the

14 CAI. CORP. CODE \& 4124; Conn. Stock CORP. ACT \& 88; Supp., § 33-370; Md. GeN. Corp. LaW $\$ 67$ (1953); Mass. Gen. Laws Ch. 156 \$ 46A(2) (1962); Neb. Rev. Stat. § 21-1, 107 (1962); NEv. REv. STAT. \$ 78.540 (1963); N.J. GEN. CoRP. LAW § 14:12-10 (1952); N.C. Bus. CoRp. ACT § 55-108.1 (1959); PENN. Bus. CoRp. LAw § 908 B (1963); W. VA. Code 31-1-63al (1953); WISc. Bus. CoRP. LAW $\$ 180.685$ (1953); D.C. Bus. CorP. ACT $\$ 72$ (1957).

15 Coro. Corp. Act $\$ 71$ (1959) (95\%); Dex. Gen. Corp. Law $\$ 253$ (1957) (90\%); IOWA BUS. CORP. ACT \& 496A-72 (1959) (95\%); MISs. CODE \& 5309-155 (1962) (95\%); N.Y. Stock Corp. Law $\S 905$ (95\%); N.D. Bus. CoRp. ACr $\$ 10-20-05$ (1957) (95\%); S.C. CODE § 12-20.5 (Supp. 1963) (95\%); TENN. GEN. CoRp. LAW \& 48-518 (1961) (90\%); UTAE Bus. CoRp. ACT \$ 16-10-70 (1961) (95\%); VA. GEN. CoRp. LAW \$ 13.1-76 (1964) $(95 \%)$.

That $\S 68 \mathrm{~A}$ of the Model Business Corporations Act provides for a short form merger where the subsidiary is less than wholly-owned (95\%), may lead more states to enact such a provision in the future. MOder Bus. CORp. ACr. ANN. § 68A If 2.01 (1960); Supp. $\S 68 \mathrm{~A}$ 2.01 (1964).

${ }^{16}$ Mass. Gen. Laws Ch. 156 \& 46A(2) (1948); Nev. Rev. Stat. $§ 78.540$ (1963); N.Y. STOCB CORP. LAW $\$ 85$.

17 Of the statutes listed in note 15 supra, only the Virginia statute does not have the cash-for-shares provision.

18 Der. GeN. CoRp. LAw $\& 253$ (a) (Supp. 1962); N.Y. Stock CORp. LAw $\S 85$.

19 Delaware: Stauffer v. Standard Brands Inc., 187 A.2d 78, 79-80 (1962); Coyne v. Park \& Tilford Distillers Corp., 154 A.2d 893, 897 (1959). New York: Rank Organization Ltd. v. Pathe Laboratories, Inc., 33 Misc. 2d 748, 751, 227 N.Y.S.2d 562, 566 (1962); Beloff v. Consohdated Edison Co., 300 N.Y. 11, 19, 87 N.E.2d 561, 564 (1949).

$20187 \mathrm{~A} .2 \mathrm{~d}$ at 80.

21 See Note, 54 Nw. U.L. Rev. 629 (1959), offering several criticisms of the short form merger as it is used in Delaware: (1) The minority shareholders in the independent corporations have greater rights than minority shareholders in a subsidiary with no rational basis for the difference in treatment; (2) the statute permits the parent to discriminate against part of the membership of the sane class; (3) the requirement of timely objection to the merger terms may cut off the minority shareholder's right of appraisal, often forcing him to take less than the fair market value for his shares; and (4) the statute has been 
cash-for-shares provision has been upheld as constitutional in both New York $^{22}$ and Delaware ${ }^{23}$ and can be used as the final step in the corporate "takeover."

\section{II}

\section{CAIIFORNIA BLUE SKY REGULATION}

Statutes designed to regulate the sale of securities and to protect the investing public, often called "blue sky"24 laws, exist in all states except Delaware. ${ }^{25}$ California's blue sky law, the Corporate Securities Law, ${ }^{20}$ provides for a substantive examination of securities offerings within the state by the California Corporations Commissioner and requires the granting of a permit by the Commissioner before securities may be "sold." 27

The pervasiveness of California securities regulation, and the rigid substantive standards that proposed securities transactions must meet, make California's system of regulation one of the most thoroughgoing in the nation. ${ }^{28}$ Section 25507 provides that the Commissioner slrall issue a permit if he finds

that the proposed plan of business of the applicant and the proposed issuance of securities are fair, just, and equitable, that the applicant intends to transact its business fairly and honestly, and that the securi-

used to extinguish vested property or ownership rights without adequate consideration of the constitutional issues involved. See also Note, B.C. IND. \& Com. L.R. 286 (1960) suggesting that it is unfair to subject a shareholder to a substantial capital gains tax by forcing him to sell in the absence of a legitimate corporate purpose. Id. at 288 .

22 Beloff v. Consolidated Edison Co., 300 N.Y. 11, 87 N.E.2d 561 (1949).

23 Coyne v. Park \& Tilford Distillers Corp., 154 A.2d 893 (Del. 1959).

24 The term "blue sky" comes from a decision of the United States Supreme Court, where, in examining the constitutionality of several of these statutes, the Court stated that they were aimed at "speculative schemes which have no more basis than so many feet of 'blue sky.'" Hall v. Geiger-Jones Co., 242 U.S. 539, 550 (1917).

25 Loss \& Cowetr, BLue Sky LAw v (1958). Prior to 1963, Nevada also had no blue sky law, but in that year, a himited act was passed. See NEv. REv. STat. $\$ \$ 90.010-90.210$ (1963).

26 CaL. CoRp. Code $\S \S 25000-26104$. For a general analysis of California's Corporate Securities Law, see Dahlquist, Regulation and Civil Liability Under California Corporate Securities Act, Pts. I \& II, 33 CaIIF. L. Rev. 342 (1945), 34 CaIIF. L. Rev. 344, 543, 695 (1946).

27 See Cal. CorP. Code $\S 25500$. This section provides: "No company shall sell any security of its own issue ... or offer for sale, negotiate for the sale of, or take subscriptions for any such security, until it has first applied for and secured from the commissioner a permit authorizing it so to do."

For a discussion of what constitutes a "sale" see notes 32-34 infra and accompanying text.

28 Schlei, State Regulation of Corporate financiad Practices 18 (1962). Sce generally Jennings, The Role of States in Corporate Regulation and Investor Protection, 23 Law \& Contear. Prob. 193, 213-20 (1958); Orschel, Administrative Protection for Shareholders in California Recapitalizations, 4 SxAN. L. REv. 252 (1952); Small, Changes in Rights, Preferences, Privileges, and Restrictions on. Outstanding Securities Under the Califormia Corporate Securities Law, 14 HAstnnGs L.J. 94 (1962); Sohieski, supra note 12. 
ties it proposes to issue and the method to be used by it in issuing or disposing of them are not such as, in his opinion, will work a fraud upon the purchaser thereof. ${ }^{2 \theta}$

The Commissioner may impose conditions on the issuance of any security in order to make the offering "fair, just, and equitable." Ad Additionally, in the case of an "exchange," the Commissioner is empowered to hold hearings as to fairness where all persons to whom securities will be issued in the exchange may appear as a inatter of right. ${ }^{31}$

California regulates not only the actual issuance of securities, but also, through a broad definition of the word "sale," the preliminary stages of a securities transaction, including "offers," "solicitations," and "negotiations." Furthermore, "sale" is defined to include an "exchange" and "any change in the rights, preferences, privileges, or restrictions on outstanding securities." It is through this latter definition of "sale" that the Commissioner attempts to insure that securities once issued are not altered so as to make them unfair, unjust, or inequitable. ${ }^{34}$

This broad definition of "sale" brings mergers and other reorganizations within the ambit of the permit procedure. ${ }^{35}$ In the case of mergers, there is a solicitation of the shareholders of the disappearing corporation to "sell" or "exchange" their shares for shares in the surviving corporation. A "negotiating permit"36 is required before the solicitation may take place, and a "definitive permit"37 must be secured before the new shares in the surviving corporation may be issued. ${ }^{38}$

${ }^{29}$ CAI. CORP. CODE $\$ 25507$. (Emphasis added.) For an evaluation of the "fair, just, and equitable" standard, see Jennings, supra note 28, at 225-28.

30 CAX. CORP. CODE $\$ 25508$.

31 CAL. CORP. CODE $\S 25510$. An "exchange" within the meaning of $\S 25510$ is an issuance of stock in consideration for other securities, claims, or property interests. While cash inay furnish part of the consideration for the issued stock, it may never furnish the entire consideration.

32 CAL. CORP. CODE $§ 25009$ (a).

${ }^{33}$ CAL. CORP. CODE $\$ 25009$ (a). See generally Small, supra note 28.

${ }^{34}$ Sobieski, supra note 12, at 84.

35 ScHLEI, op. cit. supra note 28 , at 28; Jennings, supra note 28, at 213. See Cax. CORP. CODE § 4119.

${ }^{36}$ The negotiating permit, or offering permit as it is sometimes called, requires less information than the definitive permit which is to be obtained prior to the actual issuance of securities. Usually, the negotiating permit is issued as a matter of course upon application; its issuance, however, is conditioned by the necessity of obtaining the definitive permit where a substantive examination of the proposed sale is involved. CAI. CORP. CODE $\$ \S 2551$, 25506. See generally Small, supra note 28, at 109-10; Comment, 14 HASrivgs L.J. 153 (1962).

37 The definitive permit is the permit which must be obtained prior to the actual issuance or sale of securities. It calls for the exact details of the proposed issuance or sale, the presupposition being that final agreement has been reached as to the terms of the sale. Securities sold without this permit, or whose terms vary therefrom, are voidable. See $C_{A}$. CoRp. Code $\$ \S 25500,25502-05,26100$. See generally Comment, 14 HAstrascs L.J. 153 (1962).

${ }^{38}$ The scope of the California Corporate Securities Law is much broader than the 


\section{III}

\section{THE THREE-STEP "TAKEOVER" \\ A. Step One: Acquisition of Shares in California Pump}

In the hypothetical presented at the outset, Delaware Pump Corporation must first acquire control of California Pump and Supply Company. Whether the California Corporations Commissioner will have jurisdiction over this step depends upon whether Delaware Pump secures control by acquirmg a sufficient number ${ }^{39}$ of the California corporation's shares by a stock-for-stock exchange or by a purcliase of shares for cash or other property.

The stock-for-stock excliange would be subject to the approval of the Commissioner for two reasons. First, a solicitation of the stockholders would be involved; under the Corporate Securities Law, the "solicitation of a sale" constitutes a "sale" of securities. ${ }^{40}$ Second, the plan calls for the disposition by Delaware Pump of securities of its own issue for value; this is also a "sale" under California law. ${ }^{41}$ As long as the exchange ratios were adequate and the newly issued securities were "fair, just, and equitable" in other respects, it is unlikely that the Conmissioner would object to the transaction. There is nothing inherent in the transaction which would suggest that California shareholders in California Pump and Supply would be damaged by the exchange of shares. ${ }^{42}$ Furthermore, this method may prove nore acceptable to the shareholders of California Punip than a cash purchase, since they would avoid realization of a capital gain under this plan. ${ }^{43}$

Securities Act of 1933 which excludes mergers, consolidations, and certain other reorganizations as involving no "sale." See Dahlquist, Regulation and Civil Liability Under the California Corporate Securities Act: Part II, 34 CALrF. L. Rev. 344, 350 (1946); Cowett, Reorganizations, Consolidations, Mergers, and Related Events Under the Bhe Sky Laws, 13 Bus. Law. 418 (1958). This "no-sale" theory is also found in the blue sky laws of many other jurisdictions and is incorporated in $\$ 401(\mathrm{j})(6)(c)$ of the Uniform Securitics Act. However, the California version of the Uniform Act, Assembly Bill 2531, retains the "sale" theory of California's present law. See generally Cowett, supra. For a comparison of the Uniform Securities Act with the Califorma Corporate Securities Law and a discussion of the modifications in the Uniform Act as proposed for adoption in California, see Comment, 12 Stan. L. Rev. 103 (1959). See also Jennings, supra note 28, at 220-30.

${ }^{39}$ See notes $48-49$ infra and accompanying text for a discussion of the percentage of outstanding shares needed to accomplish the second step.

40 CAI. CORP. CODE $\$ 25009$ (a).

41 CAL. CORP. Code $\$ \$ 25000,25009$ (a).

$42 \mathrm{An}$ objective examination of the step one transaction would not reveal any indication that a short form merger was being planned, since at this point the subsidiary would not be involved. However, the contrary would appear to be the case during the second-step exchange. See note 93 infra and accompanying text.

43 In certain "reorganizations," no gain or loss by a shareholder need be recognized following an exchange of like shares. Irr. REv. CoDE of 1954 \& 354(a)(1). A tax-frec 
The jurisdiction of the Commissioner could be avoided at this step if Delaware Pump Corporation chose to purchase the shares of California Pump and Supply for caslı or other property instead of issuing its own shares in an exchange. Since Delaware Pump would not be attempting to dispose of its own securities for value, the Corporate Securities Law would not apply. ${ }^{44}$

\section{B. Step Two: The Statutory Merger or Sale of Assets}

Once Delaware Pump Corporation has control of at least a majority of the California corporation's outstanding shares, ${ }^{45}$ it may proceed to the second step in the "takeover," either a statutory merger between the California corporation and a Delaware paper subsidiary created by Delaware Pump, ${ }^{46}$ or a sale of assets to the subsidiary in consideration for stock of the subsidiary.

Ultimately, the parent corporation must own nimety percent of the subsidiary's stock before a short form merger can be used, ${ }^{47}$ but initially a lesser amount is sufficient to permit the parent to effect the second step. If that step is a statutory merger, the parent corporation inust hold two-thirds of eacli class of outstanding stock, without respect to limitations on voting, to accomplish the merger unaided. ${ }^{48}$ If the second step

reorganization under the Internal Revenue Code can be effected by Delaware Pump in step one of the "takeover" provided: (1) The outstanding stock of California Pump and Supply Company is acquired by Delaware Pump in exchange solely for voting stock of the acquiring corporation; and (2) that Delaware Pump has control of Cahifornia Pump and Supply immediately after the acquisition. See INx. REv. Code of 1954 § 368(a)(1)(B). To "control" Califorma Pump and Supply Company, Delaware Pump would have to acquire at least $80 \%$ of the voting stock and at least $80 \%$ of all other classes of stock of that corporation. See INT. Rev. CoDE of 1954 \$ 368(c).

44 See CaL. CoRp. Code $\$ \$ 25009$ (a), 25500; ScEler, op. cit. supra note 28, at 24.

$45 \mathrm{In}$ its position as majority shareholder, Delaware Pump could assert immediate control over the California corporation by removing the latter corporation's board of directors and by electing its own nominees in their place. See Car. CoRp. Code $\S 810$. Directors may be removed without a showing of cause under this statute. BaLLantrone, Corporations \$ 185 (Rev. ed. 1946).

46 One of the reasons for using the subsidiary at this step in the "takeover" instead of merging the California corporation directly into the Delaware parent is that in the latter case, Delaware Pump would be exposed to the appraisal rights of its own shareholders. Dec. Gen. CoRp. Law $\S 262$ (1963). It may he difficult to determine how many shareholders would exercise this appraisal right and the resultant financial burden on the corporation from such forced purchases. LATTIN \& JennINGs, CaSEs AND MATERIAIS oN Corporations 1278 ( $3 \mathrm{~d}$ ed. 1959). Using the subsidiary solves the problem for Delaware Pump since it is the subsidiary's only stockholder at this point.

47 Det. Gen. CoRp. Law $\$ 253$ (Supp. 1962).

48 In a merger between a domestic and a foreign corporation, if the surviving corporation is to be a foreign corporation, the merger proceedings may be in accordance with the laws of the foreign corporation, provided however that the requirements of $\S 4107$ of the Califormia Corporations Code are met. CAI. CoRp. CodE $\$ 4118$. Section 4107 sets forth the requirement that holders of two-thirds of each class of outstanding stock shall approve 
is a sale of assets, the parent must exercise a majority of the voting power. ${ }^{48}$

Regardless of the technique employed, the second-step transaction will be subject to the Commissioner's supervision. If the Delaware parent desires a statutory merger between the California corporation and the Delaware subsidiary, a solicitation of California sliareholders or an offer to exchange will be involved. Under the requirements of the California Corporate Securities Law, a negotiating permit must be acquired before such solicitation may take place. ${ }^{50}$ A definitive permit would have to be obtained before the securities of the Delaware subsidiary could be issued in California, not only because of the express condition of the negotiating permit, $^{51}$ but also because the issuance of sliares for value by the Delaware subsidiary constitutes a "sale." Th2 Commissioner would thus have-jurisdiction over the entire transaction and would be called to pass upon the fairness of the proposed excliange. ${ }^{53}$

a merger. See generally Baltantine \& Sterling, Catiforma Corporation laws, 587, 589 (4th ed. 1962).

49 CAI. Corp. Code $\$ 3901$ (b).

50 See note 32 supra and accompanying text.

51 Cas. Corp. Code \$ 25517.

52 See note 33 supra and accompanying text.

53 California shareloolders could do little to protect themselves during this second step in the absence of aid from the Commissioner of Corporations. If the second step consisted of a statutory merger, no shareholder could challenge the validity or fairness of the merger in any judicial proceeding; a right of appraisal is the exclusive remedy. CaI. CorP. Cope \$ 4123; Dahlquist, supra note 38 , at 352 .

On the other hand, if the second step is a sale of assets, the transaction is subject to review by the courts as to its fairness. Section 820 of the California Corporations Code concerns the problem of self-dealing: The presence of adverse interests among a corporation's directors or the existence of a conficting duty on the part of one or more directors. It establishes, first of all, a fiduciary duty: "Directors and officers shall exercise their powers in good faith and with a view to the interests of the corporation." The section further provides that no contract or other transaction is voidable merely by virtue of a conflict of interests on the part of a director or directors provided one of three possible conditions is met: (a) The other directors know of the conflict of interests, and the contract or otlier transaction is nevertheless approved in good faith by a disinterested majority of the directors; (b) the shareholders, being fully apprised of the conflict of interests, nevertheless approve of the contract or other transaction in good faith by a majority vote; or (3) the contract or other transaction is just and reasonable to the corporation when it is approved by the directors.

Section 820 is clearly applicable in the case at hand where the directors of Cabifornia Pump and Supply, being nominees of Delaware Pump Corporation, are called upon to approve a sale of assets to the Delaware subsidiary. From the face of the statute it would appear that technical comphance is possible. Under subsection (b), the sale of assets will be upheld if a majority of the shareholders, fully apprised of all conflicts of interest, approve the transaction in good faith. Since the Delaware parent owns a majority or more of the outstanding shares of California Pump, shareholder approval is assured. Nevertheless, the California Supreme Court has held that $\$ 820$ is subject to the overriding principle tlat directors and majority shareholders are fiduciaries and must deal fairly with the corpora- 
Under the general corporation law of California, the shareholder who dissents from a statutory merger is himited to his right of appraisal unless he is attacking the mechamics of the merger $;^{54}$ all other equitable remedies have been eliminated. Under the Corporate Securities Law, however, an effective substitute exists: a permit is required before the merger may take place. ${ }^{55}$ Under section 25510 of the California Corporations Code, the Commissioner is empowered to hold hearings to ascertain the fairness of the proposed merger and would probably do so at the request of a minority shareholder; the Commissioner will deny the permit unless the merger is "fair, just, and equitable" to all shareholders affected. ${ }^{56}$

If the sale of assets technique is used instead of the statutory merger, the solicitation of shareholders would be avoided since the offer is made directly to the corporation that is to be acquired. However, since shares in the Delaware subsidiary would be issued, the Commissioner would have jurisdiction..$^{57}$ Whether he would choose to assert his jurisdiction over the transaction is another matter. As a general rule, the Commissioner is more concerned with the fairness of securities offerings where members of the general public are the prospective purchasers than with private offerings where the purchasers are supposedly more knowledgeable and better equipped to secure a fair bargain. ${ }^{58}$ It could be argued that since the offer to exchange assets for shares is made to the corporation rather than to its shareholders, there is no real need for the Commissioner to supervise the exchange. It should be noted, however, that when the sale of assets technique is used to achieve a de facto merger ${ }^{59}$ the shareholders of the corporation that has sold its assets become the

tion. In Remillard Brick Co. v. Remillard-Dandini Co., 109 Cal. App. 2d 405, 241 P.2d 66 (1952), the requirements of subsection (b) were met, but a contract which was unfair to the minority shareholders was set aside, the court stating that $\$ 820$ did not operate to limit the fiduciary duty the directors owed to all of the stockholders. Id. at $418,241 \mathrm{P} .2 \mathrm{~d}$ at 74 .

Whether judicial scrutiny will be of any assistance to the minority in the present problem is questionable. If adequate consideration is given, the only aspect of the sale of assets that might be said to be "unfair" is that it is used to set up a "freezeout" of minority shareholders by a subsequent short form merger. Even if a minority shareholder were aware of the motives of the Delaware parent, it is unlikely that le could convince the court to set aside a sale of assets for what would only be possible future unfairness.

54 Cas. CoRr. Code § 4123.

55 CAL. CoRr. CODE $\$ \S 25009$ (a), 25500; Dahlquist, supra note 38, at 352-53.

Former Commissioner of Corporations Sobieski stated the rule as follows: "[T]he appraisal rights are the exclusive rights of dissenting shareholders in a merger which the Commissioner of Corporations has found to be fair, just, and equitable." Comment, 74 Harv. L. REv. 1630, 1645 n.125 (1961).

56 CAT. Corp. Code $\$ 25510$.

57 CaL. CORP. CODE $\$ 25500$. See note 53 supra concerning the shareliolder's prospects of self-protection during this step of the "takeover."

58 See Scauer, op. cit. supra note 28, at 37-41.

59 See note 6 supra. 
shareholders of the corporation that has purchased them by virtue of a dissolution of the selling corporation and a distribution of its assets (shares in the buying corporation) to its shareholders. Since many California residents would thus become shareholders in a Delaware corporation, California's interest in supervising the transaction should be the same regardless of whether the technique is the statutory or de facto merger. ${ }^{60}$

\section{Step Three: The Short Form Merger}

If the Corporations Commissioner finds that the proposed merger (or sale of assets) between the Delaware subsidiary and California Pump is fair, and the merger (or sale of assets) subsequently takes place, the question remains whether the Commissioner has jurisdiction over the short form merger itself.

Initially, it is necessary to examine the short form merger transaction to see whether a "sale" within the meaning of the Corporate Securities Law takes place. If no "sale" is found to exist, there can be no vahd assertion of jurisdiction by the Commissioner. ${ }^{61}$

Under section 25009(a) of the California Corporations Code, the "solicitation of a sale" constitutes a "sale" of securities. Since no solicitation of shareholders takes place in the short form merger, ${ }^{62}$ and since there are no other prehminary activities sucl as negotiations or offers involved in the short form merger, ${ }^{63}$ this jurisdictional lever fails.

Nor does a "sale" occur with respect to the nimety percent of the subsidiary's stock that the parent corporation owns. There is no new "issuance" of securities of the parent in exchange for the stock of the subsidiary. ${ }^{64}$ The effect of the sliort form merger is that the stock of the subsidiary held by the parent corporation is cancelled in consideration for the assets of the subsidiary.

The only remaining basis for an assertion of jurisdiction by the Commissioner over the short form merger transaction would be if a "change in the rights, preferences, privileges, and restrictions on outstanding securities" occurs when minority shareholders are cashed out, thus resulting in a "sale" within the meaning of section 25009 (a) of the California Corporations Code. The theory behind this expanded definition of "sale" is that the effectiveness of the Corporate Securities Law would be undermined if the Commissioner of Corporations were

60 The Commissioner would also be interested in the transaction in view of the problem of self-dealing set forth in note 53 supra.

61 See CaI. Corp. Code § 25500.

62 DEL. GeN. CoRp. LAW § 253(a) (Supp. 1962); note 12 supra and accompanying text.

63 See notes 12-13 supra and accompanying text.

64 See Dex. Gen. Corp. Law \& 253 (Supp. 1962). 
unable to regulate changes in rights on outstanding securities. ${ }^{65}$ The rights and preferences of shareholders are considered by the Commissioner in his determination of whether an original issuance of securities is "fair, just, and equitable." If, once the securities have been issued, the rights of shareholders may be diminished or eliminated without his approval, the whole purpose of investor protection is thwarted. ${ }^{66}$

While the theory behind naking a change in the rights on outstanding securities a "sale" is thus clear, problems arise when an attempt is made to classify given corporate action as a change in shareholder rights within the meaning of the statute. For example, the statute says "any change," which could be read as including changes whether beneficial or detrimental $^{67}$ to holders of securities and changes whether minimal or substantial. ${ }^{68}$

The leading case where a change in the rights of shareholders was held to constitute a "sale" within the meaning of the Corporate Securities Law is Western Air Lines, Inc. v. Sobieski. ${ }^{60}$ In this case, after minority shareholders had succeeded in electing two directors of Western Air Lines by voting their shares cumulatively, the managenient moved to amend Western's articles of incorporation to ehminate cumulative voting. The Commissioner argued that cumulative voting was a substantial right of the minority and, therefore, that the change to straight voting was subject to the Commissioner's approval. ${ }^{70}$ This emphasis on the substantial nature of the change also appears in Keller Street Development Co. $v$.

65 See Sobieski, supra note 12 , at 84.

66 "What boots it that securities must be fair when sold if, immediately after the money has been collected, they can be converted into unfair securities." Ibid.

See also, Western Air Lines, Inc. v. Sobieski, 191 Cal. App. 2d 399, 413-14, 12 Cal. Rptr. 719, 728 (1961):

[T]o follow the argument of Western to its conclusion, would be to say that the commissioner might have the power in the first instance to require certain rights to be guaranteed to shareholders before he would permit the sale or issuance of a foreign corporation's stock in this state, but that immediately thereafter, by the device of amending the charter of such corporation in another state, the entire structure of that corporation, even to substantial changes in the rights of shareholders in Cahfornia, might be legally effected. Such a holding would enable a foreign corporation to destroy the rights which the State of California has deemed worthy of protection by the enactment of the Corporate Securities Act.

67 See Small, supra note 28 , at 97.

68 See 36 CaL. Ops. ATT'y Gen. 12, 15 (1960).

69191 Cal. App. 2d 399, 12 Cal. Rptr. 719 (1961), noted: 49 CALIF. L. Rev. 974 (1961); 1962 Duke L.J. 109; 46 MnNN. L. Rev. 765 (1962); 15 S.C.L. Rev. 582 (1963); 9 U.C.L.A. L. REv. 242 (1962).

70 Brief for Appellant, pp. 48-53, Western Air Lines, Inc. v. Sobieski, 191 Cal. App. 2d 399, 12 Cal. Rptr. 719 (1961). See also Matter of New York Hanseatic Corp., 200 Misc. $530,536,103$ N.Y.S.2d 698, 703 (Sup. Ct. 1951) ("right to cumulative voting is a valuable one for minority shareholders."); N.Y. STOCK CoRP. LAw § 38-11(d) (giving shareholders appraisal right if charter amendment abolishes or himits voting rights). 
Department of Investment, ${ }^{71}$ where the court held that a charter amendment making previously nonassessable stock assessable constituted a "sale" of securities requiring a permit. ${ }^{72}$ It would therefore appear that, as a minimum, any substantial change in the rights on outstanding securities constitutes a "sale" of securities under section 25009 (a). ${ }^{73}$ The typical change would be an amendment to the articles of incorporation, since the rights, preferences, privileges, and restrictions on a corporate security are generally set forth therein. ${ }^{74}$ Other changes might be those amending corporate by-laws $\mathrm{s}^{75}$ (for example, a restriction on the transfer of shares) or certificates of determination of preferences. ${ }^{76}$

It is doubtful, however, that the short form merger used as a "freezeout" device produces a change $\mathrm{m}$ rights on outstanding securities held by the minority shareholders within the meaning of section 25009 (a). It is true that Califormia shareholders lose all rights when they are forced to sell their shares to Delaware Pump; it is appealing to argue that if the elimination of cumulative voting in Western Air Lines is a "sale," a fortiori the elimmation of all of a shareholder's rights must be a "sale." Nevertheless, the scope of the statute appears to be confined to changes in the nature of the securities themselves, ${ }^{77}$ and therefore does not include cashing out shareholders.

As section 25009 (a) is concerned with the definition of "sale," it must be read in connection with section 25500 which sets forth the prohibition of the Corporate Securities Law that "no company shall sell any security of its own issue" without having acquired authorization from the Corporations Comnnissioner. To make the short form merger subject to regulation by the Commissioner would be to hold that Delaware Pump Corporation sells securities of its own issue by paying the subsidiary's stockholders the value of their shares. When iminority shareholders are cashed out in the short form merger process, something similar to a stock redemption or a dissolution of the corporation as to the minority shareliolders occurs; in both redemption and dissolution, rights are eliminated, but there is no "issuance" of stock, and therefore no "sale."

This interpretation coincides with the administrative regulations promulgated by the Commissioner. Regulation 760 provides: "Any change in rights, preferences, privileges, or restrictions on outstanding securities

71227 A.C.A. 840, 845, 39 Cal. Rptr. 44, 46 (1964).

72 Id. at $843-44,39$ Cal.'Rptr. at $45-46$.

${ }^{73}$ Cf. United States v. New York, N.H. \& H.R.R., 276 F.2d 525, 530 (2d Cir. 1960), cert. denied, 362 U.S. 961 (1960).

74 See CAL. CoRp. Code $\$ \S 304,1100,1102$.

75 See CaI. Corp. Code $\$ 501(\mathrm{~g})$; Small, supra note 28, at 105-06.

76 See Car. Corp. Code $\$ 1102$.

${ }^{77}$ Small, supra note 28 , at 97. 
constitutes the sale and issuance of a new security requiring a permit."78 In the Commissioner's brief in the Western Air Lines case, the reasoning behind this regulation is set forth: a change in rights or privileges on outstanding securities constitutes a "sale" of securities because once that change is made, an "exchange" takes place by operation of law. ${ }^{79}$ While a corporation will rarely go through the physical motions of calling old stock in and issuing new certificates with different rights, the contract between the corporation and the shareholder has nevertheless been changed so that a new, modified security is "issued." Viewed as an "exchange" or as the "issuance" of a new modified security, it is apparent that no change in rights or privileges on outstanding securities takes place in the short form merger as to minority shareholders.

To find that, as a matter of statutory construction, no "sale" occurs in the short form merger is not to say that the Commissioner could not, under an amended statute, constitutionally exert jurisdiction over the transaction. Under the present version of section 25009(a), a "sale" exists where only voting rights are changed, and yet, where all of a shareholder's rights are eliminated, a "sale" does not exist merely because there is no "issuance" of a new security in the short form merger. An amendment to section 25009 (a) would be desirable, providing that a "sale" shall be deemed to exist where security holders of a corporation are deprived of all rights, preferences, privileges, and restrictions on their securities in any merger or consolidation procedure even though no "exchange" occurs in said procedure.

If section 25009 (a) were amended to specify that a "sale" takes place in the short form merger, any constitutional challenge agamst regulation of the transaction by the Commissioner would have to rest upon the claim that Cahifornia has so little interest in the transaction to make regulation by the Commissioner unreasonable. ${ }^{81}$ California, however, has substantial interest in the short form merger transaction. In the first place, a maximum of ten percent of the Delaware subsidiary's stock may be owned by California residents; ${ }^{82}$ this ten percent is one hundred percent of the

7810 CAL. ADARN. CoDE $\$ 760$. (Emphasis added.)

79 Brief for Appellant, pp. 30-31, 191 Cal. App. 2d 399, 12 Cal. Rptr. 719 (1961).

80 Ibid. Cf. Umited States v. New York, N.H. \& H.R.R., supra note 73.

81 See Latty, Pseudo-Foreign Corporations, 65 YAIE L.J. 137, 163-64 (1955). See generally Loss, The Conflict of Lawes and the Blue Sky Lazes, 71 HaRv. L. REv. 209 (1957); Reese \& Kaufman, The Law Governing Corporate Afairs: Choice of Law and the Impact of Full Faith and Credit, 58 Cosus. L. Rev. 1118 (1958); Sobieski, supra note 12, at 81-84; Note, CAIIF. L. REv. 974 (1961).

82 Of course, the percentage of California shareholders may be considerably less than 10\%. Originally, California Pump and Supply Company may bave had many out-of-state stockholders. If this is the case, presumably some of these will still be reflected in the $10 \%$ of the stock that the Delaware Pump Corporation does not yet possess. Also, Delaware 
shareholders who may suffer loss as a result of the short form merger. Secondly, the Delaware subsidiary is commercially domiciled in California. Finally, the substance of the "sale" that occurs under the amended version of the statute would appear to take place in Cahifornia.

This last conclusion is based in part on the appellate court's rejection of an argument advanced by the respondent in the Western Air Lines case. The trial court in Western held that the Commissioner had acted without or in excess of his jurisdiction because the change in rights of Western's shareholders would have been accomplished outside the state by the filing of a certificate of amendment with the Delaware Secretary of State. ${ }^{83}$ The district court, however, found this act to be merely the last act necessary to complete the change from cumulative to straight voting, insufficient to divest the Commissioner of jurisdiction. ${ }^{84}$ Other cases support this view. ${ }^{85}$

It thus becomes apparent that filing the certificate of merger with the Delaware Secretary of State-the last act necessary to effect the short form merger-is not decisive. Also, the state in which the directors of Delaware Pump meet to pass the resolution to merge is of little significance. 86

The decisive factor in determining where a change in riglits on outstanding securities occurs would appear to be the situs of the shares, which in turn is determined by the comniercial domicile of the corporation and the residence of the shareholders. ${ }^{87}$ The Commissioner argued in

Pump may own more than $90 \%$ of the subsidiary's stock required for the short form merger thereby reducing the percentage held by Califormia residents.

However, no "sale" takes place in the short form merger with respect to the shares owned by the parent corporation. See note 64 supra and accompanying text. If, under an amended version of $\S 25009$ (a), a "sale" could be found to exist, that "sale" would be similar to a change in rights on outstanding securities and would occur only in relation to the minority shares. Therefore, while California residents may own only $10 \%$ of the total shares of the Delaware subsidiary, they may own up to $100 \%$ of the stock with respect to which a "sale" would occur. To the extent, however, that less than 10\% of the subsidiary's stock is owned by California residents, the more tenuous is the Commissioner's power to regulate the transaction.

83191 Cal. App. 2d at 404-05, 12 Cal. Rptr. at 723.

84191 Cal. App. 2d at 406, 12 Cal. Rptr. at 723-24. Actually, the state where the change in rights on outstanding securities was to take place was irrelevant to the decision in Western. Two "sales" took place in that case: the solicitation of shareholders, which was necessary to effect the change, and the change in voting rights. Simce the solicitation took place in Cahforma, adequate grounds existed for an exercise of jurisdiction by the Commissioner over the entire transaction.

85 People v. Rankin, 169 Cal. App. 2d 150, 337 P.2d 182 (1959); People v. Sears, 138 Cal. App. 2d 773, 292 P.2d 663 (1956).

86 Western's board of directors met in Nevada to pass the charter amendment; this fact was never mentioned by the court.

87 Mobilia sequuntur personam. This rule may not always be decisive as to the situs of stock. See Southern Pac. Co. v. McColgan, 68 Cal. App. $2 d 48$ (1945). However, where 
Western that since Western Air Lines was a pseudo-foreign corporation commercially domiciled in California and doing no business in Delaware, its place of incorporation, the shares of Western owned by Califorina residents would have their situs in California, and therefore a change in the rights of these shares would occur in Califorma. ${ }^{88}$ This same argument could be used in the instant case against the assertion that any attempt by the Commissioner to regulate the short form merger would be an attempt to exert extra-territorial jurisdiction. ${ }^{89}$

\section{CONCLUSION}

The conclusion that the Commissioner of Corporations would not have jurisdiction over the short form inerger because, as a matter of statutory construction, no "sale" exists in the transaction, leads to two alternative methods whereby Cahifornia shareholders nay nevertheless be protected. First, as previously suggested, ${ }^{90}$ section 25009 (a) should be amended. In the absence of an aniendment, if the Commissioner is not to leave California residents with an appraisal right exercisable only in Delaware ${ }^{91}$ he must protect minority shareholders during the second step of the corporate "takeover" where he clearly has jurisdiction. ${ }^{92}$ The use

the residence of the stockholders and the commercial domicile of the corporation coincide, it should be valid.

88 Appellant's Reply Brief, Western Air Lines, Inc. v. Sobieski, 191 Cal. App. 2d 399, 12 Cal. Rptr. 719 (1961), pp. 48-5\%.

89 Dahlquist, supra note 38 , at $380-81$ states that

[N]o part of the [Corporate Securities] Act purports to have extraterritorial effect. . . Therefore, where it is clear that all parts of the transaction, both the preliminary acts as well as the actual issue of the security, take place outside California, it is axiomatic that no permit is required.

Several cases appear to prevent the apphication of Corporate Securities Law to out-of-state transactions even though some preliminary activities took place in California: Robbins v. Pacific Eastern Corp., 8 Cal. 2d 241, 65 P.2d 42 (1937); In re Motor Prod. Mfg. Corp., 85 F.2d 318, modified on rehearing, 90 F.2d 8 (9th Cir. 1936), cert. denied, 302 U.S. 693 (1937); Jones v. Re-Mine Oil Co., 47 Cal. App. 2d 832, 119 P.2d 219 (1941). For example, in the Robbins case, although the solicitation of an exchange took place in California without a permit, the Corporate Securities Law was held not to apply to the out-of-state delivery of shares. These cases must be read, however, in hight of the voiding provision of the Califormia statute which at that time applied only if a security was "issued" without a permit or at variance with its terms. See Loss, supra note 81 , at 220, 234-36. The present Cahfornia voiding statute, Corporations Code $\$ 26100$, applies not only to those securities "issued" by a corporation, but also to those "sold." Consequently, some doubt is cast on the authority of the above-cited cases. Loss, supra. See also, Intermountain Title Guar. Co. v. Egbert, 52 Idaho 402, 16 P.2d 390 (1932). In this case, the sale of stock, completed outside the state, was held voidable because negotiations for the sale were inade in Idaho without complying with that state's blue sky law.

90 See text accompanying notes 80-81 supra.

01 See Sobieski, supra note 12, at 79, for a former Cahfornia Corporations Commissioner's view on the value of an appraisal right in Delaware.

92 See Part III-B of this Comment. 
of a paper subsidiary and ownership of a large percentage of stock in the California corporation by the Delaware parent should serve as a warning that a short form merger is in the offing and that protection is needed. ${ }^{03}$

Before approving the second-step statutory merger or sale of assets, the Commissioner could give mimimum protection by requiring that minority shareholders be apprised that their right to continue their investment is at best precarious, that once the parent corporation acquires nimety percent of the outstanding stock, they may be eliminated at will. In the case of a statutory merger, such notice would at least give the minority shareholders appraisal rights in Cahifornia if they chose to dissent at the second step rather than the third. ${ }^{04}$

The Commissioner, however, is not himited to compelling disclosure. By statutory grant, the Commissioner has considerable discretion in imposing conditions ${ }^{05}$ lie has used his conditioning power to the advantage of minority shareholders as In the Matter of Yellow and Checker Cab Co. (Consolidated $)^{06}$ demonstrates. In this case, the applicant sought to merge its wholly-owned subsidiary. The Commissioner imposed two conditions upon the permit: one specifying the percentage of certain class of shareholders that would have to approve the plan and the second setting forth the amount that dissenting shareholders would have to be paid, thus eliminating the expense and trouble for the shareholder that would be mvolved in asserting his statutory appraisal remedy.

One method of protecting mimority shareholders in the problein at hand might be for the Commissioner to give thein contractual rights against the subsidiary by requirmg that the corporation amend its articles to prohibit a subsequent short form merger between it and any other

${ }^{03}$ In Stauffer v. Standard Brands Inc., 178 A.2d 311 (Del. Ch.), aff'd, 187 A.2d 78 (Del. 1962)-the case upon which the hypothetical in this Comment is based-minority shareholders knew prior to yoting for the second step statutory merger that a short form merger would follow. $178 \mathrm{~A} .2 \mathrm{~d}$ at 312 . It is conceivable that failure by the parent to diselose plans to execute a short form merger following the second step would be a violation of SEC Rule 10(b)-5. Cf. Speed v. Transamerica Corp., 99 F. Supp. 808 (D. Del. 1951).

04 If the sale of assets technique were used to accomplish this second step, shareholders would not have an appraisal remedy; right of appraisal applies only to mergers and consolidations. See CaL. Corp. Code § 4300; Dex. Gen. Corp. Law § 262 (1963).

Notice of the parent corporation's intention to execute a short form merger might also warn California stockholders that going into the Delaware subsidiary might result in a decrease in the value of their investment. If the Delaware parent needs additional outstanding shares to reach the $90 \%$ necessary for the short form merger, dividends may be withheld until a sufficient number of shareholders sell.

05 "The Commissioner may impose ... such ... conditions as he deems reasonable and necessary or advisable for the protection of the public and the purchaser of the securities." CaL. CoRp. CODE $\S 25508$.

96 Cal. Corp. Comm'r File No. SF52659 (1945) discussed in Orschel, Administrative Protection for Shareholders in Californic Recapitalizations, 4 STAN. L. REV. 215, 225-27 (1952). 
corporation..$^{97}$ In view of Langfelder $v$. Universal Laboratories, Inc., ${ }^{98}$ however, such a condition may not be successful. In this case, the plaintiffs, owners of preferred stock of an acquired corporation, contended that their stock had been reduced by the merger and that they were entitled to 110 percent of the amount of the reduction by virtue of a contractual provision in the charter of the acquired corporation. Assuming that a reduction had taken place, the court held that under Delaware law the contract provision offered the preferred shareholders no protection because it was converted with all other contractual rights inherent in stock ownership by the terms of the merger. ${ }^{99} \mathrm{~A}$ condition that the subsidiary amend its articles to provide, for instance, that the approval of minety-mine percent of its stockholders would be necessary to effect a short form merger would seem to be ineffective for the same reasons the protective provision failed in the Langfelder case.

If, in the instant problem, the Commissioner required, as a condition of granting the permit, the filing of an undertaking ${ }^{100}$ by the subsidiary providing that minority shareholders will receive 110 percent $^{101}$ of the

87 It may be that such a prohibition would not be "reasonable and necessary or advisable" under § 25508 of the Corporations Code, especially if the minority's shares were subject to redemption under the corporate charter. Perhaps California's interest reasonably extends only to ensuring minority shareholders an easily accessible appraisal remedy or in compensating minority shareholders for the loss of their right to continue their investunent in the event of a short form merger.

98163 F.2d 804 (3d Cir. 1947).

99 Id. at 808 .

100 The Securities Exchange Commission recently adopted the undertaking technique in connection with certain merger, consolidation, and asset sales transactions. Under SEC Rule 133, mergers, consolidations, and certain other fundamental corporate changes are considered to involve "no sale." See note 38 supra. A 1959 amendment to Rule 133 authorized the use of a simplified form in connection with Rule 133 transactions, which, however, included an undertaking requirement that registration information be kept current for a period of twenty-four months. See Throop, Recent Developments with Respect to Rule 133, 15 Bus. LAw. 119, 127-30 (1959).

While objections have been raised to the use of the undertaking in federal regulation of securities, they seem to be based on the authority of the SEC. See Throop, supra at 127: "It would seem that, to the extent an undertaking (other than one specifically prescribed by statute) does no more than obligate an issuer to do what is required by law, it is unnecessary; and that, to the extent that an undertaking imposes an obligation to do something not required by law, it is unwarranted." These objections would appear inapplicable if the technique were used by the California Corporations Commissioner in view of his broad discretion under $\$ 25508$ of the California Corporations Code. See note 95 supra.

101 The reason for giving the minority shareliolders a $10 \%$ bonus is to compensate them for the loss of their right to continue their investment. In a merger between two California corporations, or between a California corporation and a foreign corporation incorporated in a state that does not permit a "freezeout" by the short form merger, shareliolders in the disappearing corporation have a right to receive shares in the surviving corporation. See notes $1 \& 9$ supra and accompanying text. Since this right is forfeited in the instant case at the second step because the surviving corporation (Delaware Pump's 
value of their stock upon being forced out in a subsequent short form merger, minority shareholders could be protected. In this manner, the Commissioner should be able to overcome the problems posed by the Langfelder case. ${ }^{102}$ The use of the undertaking technique would appear to free the shareholder's right from the objection that it is merely another contractual right inherent in or incidental to stock ownership, the duty imposed by the undertaking runming primarily to the Commissioner and only secondarily to the minority shareholders. Section 253(b) of the Delaware General Corporation Law, providing that the corporation surviving a short form merger shall be hable for all obligations of the disappearing corporation, should make the condition imposed upon the second-step permit binding upon the parent. As a precautionary measure, however, the Commissioner should always require that the parent corporation, in addition to the subsidiary, file an undertaking to comply with the conditions contained in the permit. Binding the parent by the undertaking technique would ensure the survival of any right granted minority shareholders by the Commissioner.

The undertaking could also be effectively used to give California shareholders a local forum for their appraisal remedy if they were forced out in a short form merger. California would appear to be the most convenient state since the subsidiary conducts its business there and since, presumably, most of the subsidiary's shareholders are California residents. ${ }^{103}$

While the short form merger may not be unconstitutional, it nevertheless produces substantial unfairness if minority shareholders are eliminated from an enterprise in the absence of a legitimate corporate purpose. Used as the final stage in a corporate "takeover" of a Cahifornia corporation, the short form merger produces inequities which seem to clash with

subsidiary) is a Delaware corporation, compensation for the loss seems appropriate. On the Commissioner's use of the compensatory principle to ensure fairness, see Orschel, Administrative Protection for Shareholders in California Recapitalizations, 4 Stan. L. REv. 215, 224-30 (1952).

102 It may be that Langfelder should not be extended beyond its facts. The case has been criticized. Note, 61 Harv. L. Rev. 1060 (1948); cf. Car. Corp. Code $\$ 4123$. This section authorizes a contractual provision that would protect a holder of shares of any class whose terms and provisions expressly set forth the amount to be paid upon a merger or consolidation. That the right given the minority shareholders by the Commissioner would exist independent of the corporate charter may be a sufficient basis on which to distinguish the Langfelder decision.

103 But see note 82 supra. If, for example, one-fifth of the minority shareholders reside outside California and exercise their appraisal renedy in Delaware, while the remaining minority shareholders seek a California appraisal pursuant to the undertaking agreenrent, possible inequality of treatment of the two groups may result. Cf. Weiss v. Routh, 149 F.2d 193, 196 (2d Cir. 1945). It would seem, however, that by agreeing to the undertaking, the parent could not object to having to defend in two forums. 
the traditional concepts of California blue sky regulation and investor protection. Yet the present statutes appear inadequate; the California Corporations Commissioner is unable to assert jurisdiction directly over a short form merger transaction even though the subsidiary that is merged is comnercially domiciled in California and most, if not all, of the minority shareholders eliminated are Cahifornia residents. Although the Commissioner can protect California sharelolders under his conditioning power and by use of the undertaking technique at the second step of the "takeover," his protection is limited by the foreseeability of a subsequent short form nierger. A statutory amendment, broadening the concept of a "sale," would appear to be the desirable solution.

D. Keith Bilter 